Final Report

On

Energy Consumption of Die Casting Operations

US Department of Energy Grant/Contract No.

DE-FC07-00ID13843

OSURF Project No. 739022

Report Period: March 1, 2000 to May 31, 2003

\begin{abstract}
Principal Investigators:
Jerald Brevick, Clark Mount-Campbell, Carroll Mobley

The Ohio State University
\end{abstract}

March 15, 2004 


\section{Final Report: Energy Consumption of Die Casting Operations}

\subsection{Background}

Molten metal processing is inherently energy intensive and roughly $25 \%$ of the cost of die-cast products can be traced to some form of energy consumption [1]. The obvious major energy requirements are for melting and holding molten alloy in preparation for casting. The proper selection and maintenance of melting and holding equipment are clearly important factors in minimizing energy consumption in die-casting operations [2]. In addition to energy consumption, furnace selection also influences metal loss due to oxidation, metal quality, and maintenance requirements. Other important factors influencing energy consumption in a die-casting facility include geographic location, alloy(s) cast, starting form of alloy (solid or liquid), overall process flow, casting yield, scrap rate, cycle times, number of shifts per day, days of operation per month, type and size of die-casting machine, related equipment (robots, trim presses), and downstream processing (machining, plating, assembly, etc.). Each of these factors also may influence the casting quality and productivity of a die-casting enterprise. In a die-casting enterprise, decisions regarding these issues are made frequently and are based on a large number of factors. Therefore, it is not surprising that energy consumption can vary significantly from one die-casting enterprise to the next, and within a single enterprise as a function of time.

The influence of local decisions within a die-casting enterprise on energy consumption is often difficult to determine because of the scale and complexity of die-casting operations. A change made in one aspect of the system may not have the degree of impact anticipated on the entire die-casting system. In addition, individual components of the die casting system are not often metered for energy consumption, making it very difficult to assess the actual influence of enterprise decisions on energy consumption. Therefore, the overall objective of this research project was to develop models for die-casting operations that can be used to assess the influence of equipment or process changes on energy consumption.

\subsection{Approach}

The general approach of this project was to conduct a literature review regarding energy use in die-casting, and then create and distribute a survey regarding energy consumption to North American Die Casting Association (NADCA) corporate members. The survey responses were then collected and evaluated. The goal of these activities was to establish an accurate flow chart capable of mapping energy inputs for the die-casting industry. Also, these data were used to determine the relative importance of various energyconsuming operations in die-casting, and to determine the amount and quality of energy data available in the industry. In addition to energy survey data, selected energy audits of die-casting operations at the The Ohio State University (OSU) die-casting laboratory and 
at industry sites were conducted. The purpose of these audits was to establish the relative amount of energy required by various die-casting operations, such as alloy melting, alloy holding, and the die-casting operation itself. Based on the information derived from the energy survey and on-site energy audits, computer-based models were developed that allow the energy "journey" in die-casting operations to be assessed.

\subsection{Project Activities and Accomplishments}

The activities performed during the first two years of this project were previously described in first (3/01) and second year (3/02) annual reports. This final report summarizes the activities of the third year of the project and overall results of the study.

\subsection{Energy Survey of the Die Casting Industry}

In the first year of the project, a list of 141 die-casting companies was generated with the assistance of the North American Die Casting Association (NADCA) Capability Directory. These companies represented a diverse cross-section of the die-casting industry in terms of the alloys cast, type of customers and products, annual tonnage of castings produced, types of melting, and degree of automation. The energy survey that was actually distributed to the industry is attached as Appendix A.

General industry response to the survey was very poor. Of the 8 responses received, only 2 possessed enough information to be useful. This response rate was very low, so followup phone calls were made to selected die-casters to try to improve the response rate and to inquire as to why they chose not to fill-out and return the surveys. Most indicated that they simply did not have the energy data requested, some indicated that they did not have the time or manpower to fill out and return the energy survey, others said the survey was too long and complex. No additional completed surveys were obtained as a result of the phone calls. Table 1 is a summary of energy data collected via the survey and a followup visits to the 2 survey respondents (DC1 and DC2).

Table 1. Energy Summary From Survey Respondents*

\begin{tabular}{|l|l|l|l|l|}
\hline Facility & Castings Sold/Year & Electricity Use & Natural Gas Use & Total Energy \\
\hline $\mathrm{DC} 1$ & $14,800,000 \mathrm{lb}$ & $2,252 \mathrm{Btu} / \mathrm{lb}$ & $27,237 \mathrm{Btu} / \mathrm{lb}$ & $29,489 \mathrm{Btu} / \mathrm{lb}$ \\
\hline $\mathrm{DC} 2$ & $55,078,546 \mathrm{lb}$ & $1,920 \mathrm{Btu} / \mathrm{lb}$ & $1,824 \mathrm{Btu} / \mathrm{lb}$ & $3,744 \mathrm{Btu} / \mathrm{lb}$ \\
\hline
\end{tabular}

*The conversion factor for electricity/natural gas energy equivalence was taken as $3412 \mathrm{Btu}$ per KWH and the energy content of natural gas was taken as $1000 \mathrm{Btu} / \mathrm{cubic}$ foot.

The two energy survey respondents are both located in the upper Midwest and are high volume cold chamber aluminum die-casting facilities. Table 2 summarizes pertinent information associated with the DC1 and DC2 casting facilities. DC1 is a department located in a large building also occupied by machining and assembly operations. Natural gas and electricity for the casting department are not entirely metered separately from the larger facility. Therefore, the survey respondent was forced to make some estimations of 
relative energy use for the casting department. DC1 purchases approximately $90 \%$ of its aluminum molten via truck shipment, the remaining $10 \%$ is purchased in ingot form. DC1 has a total of 29 cold chamber die-casting machines and each is accompanied by a 2,500 pound electric resistance holding furnace. This facility has 3 natural gas fired furnaces available for receiving molten metal deliveries and for re-melting casting offal and casting scrap. The capacities of these furnaces are 60,000 pounds, 40,000 pounds and 4,000 pounds. Metal loss due to dross and floor spillage is reported as $4.75 \%$. The average casting yield at $\mathrm{DC} 1$ is $68 \%$, and the average platform and downstream inspection scrap rate before machining is 7\%. DC1 typically operates 2 shifts per day and 5 to 6 days per week, depending on production demand. This facility has 29 highly mechanized die-casting cells that include automatic ladlers, extractors, sprayers, and trim presses.

Table 2. Summary Information of Survey Respondents

\begin{tabular}{|c|c|c|}
\hline Feature & DC1 & DC2 \\
\hline Central Melting/Holding & $\begin{array}{l}1-60,000 \mathrm{lb} \text { gas-fired } \\
1-40,000 \mathrm{lb} \text { gas-fired } \\
1-4,000 \mathrm{lb} \text { gas-fired }\end{array}$ & $\begin{array}{l}\text { 2-70,000 lb gas-fired (melters) } \\
\text { 2-90,000 lb electric resistance } \\
\text { reverb (receiving/holding) }\end{array}$ \\
\hline Holding at Machine Cell & $\begin{array}{l}29-2,500 \mathrm{lb} \text { electric } \\
\text { resistance (radiant) }\end{array}$ & $\begin{array}{l}28-4,000 \mathrm{lb} \text { electric } \\
\text { resistance (radiant) }\end{array}$ \\
\hline Metal Loss & $4.75 \%$ & $3 \%$ \\
\hline Die Casting Machines & $\begin{array}{l}8-600 \text { ton } \\
19-800 \text { ton } \\
2-1,000 \text { ton }\end{array}$ & $\begin{array}{l}5-450 \text { ton } \\
2-600 \text { ton } \\
1-1,000 \text { ton } \\
2-1,200 \text { ton } \\
16-1,600 \text { ton } \\
2-2,000 \text { ton }\end{array}$ \\
\hline Average Casting Yield & $68 \%$ & $67 \%$ \\
\hline Scrap Rate & $7.0 \%$ & $7.5 \%$ \\
\hline Hours of Operation & 2-8 hr shifts, 5+ days/week & 2-8 hr shifts, 5+ days/week \\
\hline
\end{tabular}

The second facility, DC2, is housed in a building by itself - although it is on the same parcel of land as facilities housing downstream machining and assembly operations. The natural gas and electricity for casting operations are metered independently for DC2 operations. DC2 supplied energy and casting production information for a 6-month period (June-November), and these data were simply multiplied by 2 to arrive at the annual information shown in Table 1. DC2 purchases its entire supply of aluminum molten via truck delivery. Two electric resistance reverberatory ("reverb") furnaces of 90,000 pounds capacity each are available to receive and hold the molten alloy at temperature. DC2 also has available 2 natural gas-fired melting/holding furnaces of 70,000 pounds capacity each, which are used primarily for re-melting casting offal and casting scrap. This facility has 28 cold chamber die-casting machines and each is accompanied by a 4,000 pound electric resistance holding furnace. Metal loss due to dross and floor spillage is reported as 3\%. The average casting yield at DC2 is $67 \%$ and 
the platform and downstream inspection scrap before machining is $7.5 \%$. DC2 typically operates 2 shifts per day, 5 to 6 days per week, depending on production demand. Most cells in this facility utilize an automated ladler, extractor, and sprayer.

The energy survey data summary in Table 1 shows the DC1 and DC2 facilities to be very different in terms of energy per pound of castings sold. However, in Table 2, DC1 and DC2 appear to be similar operations. There may be several reasons for the large reported difference. First, the survey was a "top down" approach, relying primarily on gross production numbers and energy data - some of which involved estimates. Surveys can be a useful approach, but significant errors may develop not only from the estimation issue, but also from the "energy per pound" approach, and the relative efficiency of electricity versus gas within a die-casting enterprise.

If the survey data are based on actual data from a short time frame (one month), the annualized data could be significantly in error due to equipment problems that cause short-term changes in operation. For example, if a large furnace used for re-melting scrap goes down for repairs for a month, the scrap could either be sold or kept in inventory to be melted later. Assuming casting production remains constant, via buying molten metal from an outside source, during that month the furnace was out of service the survey reported energy per pound of castings sold would be significantly less than typical. However, the cost (amount purchased) of aluminum alloy to the die-casting enterprise would be much greater during that month - but the survey would not capture this information. Conversely, short-term slowdowns in casting production would most likely artificially increase the energy per pound of castings sold. Holding molten aluminum represents a fixed cost because holding furnaces consume energy 24 hours a day, 7 days a week - whether castings are being produced or not. Finally, from the point of view of an individual die-casting enterprise, electric heating and melting is 2 to 3 times more energy efficient than gas melting in terms of Btu/lb. From the survey perspective, die-casters melting and holding alloy using electric equipment would report significantly less energy per pound of castings sold than die-casters using natural gas. However, from a larger system perspective, energy was expended to produce the electricity elsewhere, and the die-casting enterprise pays a higher price per Btu for electricity than natural gas. The $\mathrm{Btu} / \mathrm{lb}$ metric from the survey would not capture this disparity without additional analysis.

One of the original ideas of this project was to evaluate the data collected by the energy survey using a method called Data Envelopment Analysis (DEA) [3][4]. Figure 1 illustrates the method in very simple two-dimensional terms of kilowatt-hours $(\mathrm{KWH})$ required per ton of aluminum castings sold. The energy data collected from the survey were to be used to establish an "efficient frontier" to show what die-casting companies are the most efficient in a variety of categories. Die-casters could have used the results of the DEA as a benchmark to compare their own operations with others. Unfortunately, not enough data were collected via the energy survey to employ this method for this project. Regardless, the energy information acquired via a survey instrument may have been quite difficult to use as a true measure of the energy efficiency of a die-casting enterprise. 


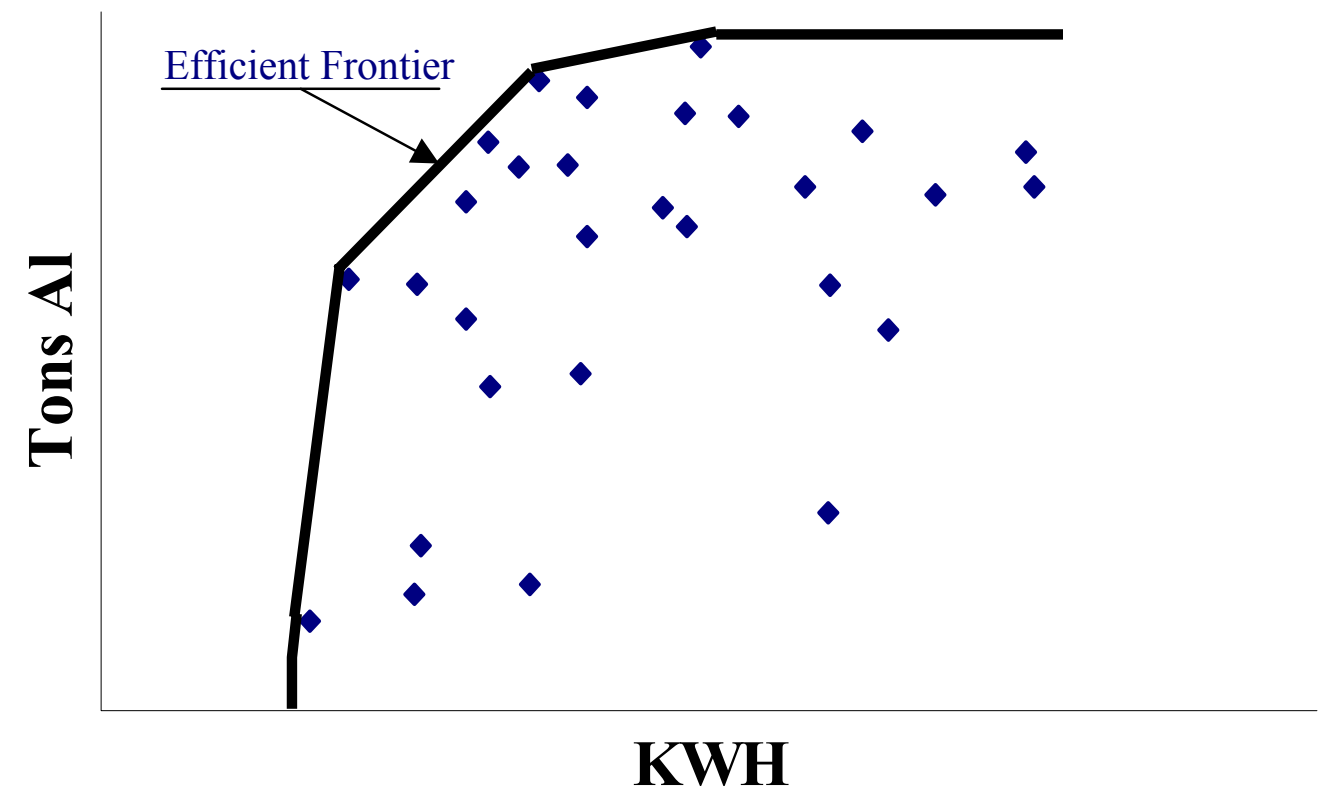

Figure 1. Conceptual plot illustrating the Data Envelopment Analysis (DEA) technique for an evaluation of tons of aluminum die-castings sold versus kilowatthours (KWH) of electricity used.

Another goal of the survey was to establish an accurate flow chart to map energy inputs for the die casting industry. This aspect of the survey was successful, and was very useful in the development of the energy models. Since the 2 interested respondents were aluminum cold chamber die-casting facilities, it was decided to focus the project on the development of energy models based on this process. Also, the overall response to the energy survey suggests that amount and quality of energy consumption data available in the die-casting industry is very poor, especially among small die-casting enterprises, and that interest in energy consumption among die-casters is generally low in comparison to day-to-day production issues.

\subsection{Energy Audits: Energy Consumed in the Form of Natural Gas}

An alternate technique to the energy survey is a "ground-up" approach to determining energy consumption. This involves summing-up the published or measured energy consumption rates for the specific equipment used in each die-casting enterprise to determine the amount of energy consumed. To this end, energy meters were purchased for the project and audits were accomplished at both OSU and at industry sites.

Experiments for determining the efficiency of the OSU gas-fired stationary crucible melting furnace were conducted at the OSU Engineering Research Center for Net Shape Manufacturing (ERC-NSM) laboratory. The furnace is a MPH 500 pound capacity furnace with upper temperature capability of $2000^{\circ} \mathrm{F}$. Regrettably this furnace has no cover. The experiment was conducted using aluminum A380 die-casting alloy. The 
thermal properties of A380 were obtained for theoretical calculations of the overall efficiency of the furnace. The energy used to heat, melt and superheat the A380 was measured by means of a gas meter manufactured by the Sprague Meter Co. Bridgeport, CT which was installed in the main gas supply line to the furnace.

For example, 80 pounds of $\mathrm{A} 380$ in ingot form was added to the room temperature furnace and melted. The aluminum was superheated to $677^{\circ} \mathrm{C}$ before the gas was turned off. Shortly thereafter, 20 pounds of dry, room temperature A380 ingot was added to the melt. This brought the melt temperature down quickly and the furnace was re-started until a temperature slightly above of $677^{\circ} \mathrm{C}$ was again achieved, and the gas usage recorded. This sequence was repeated 3 times until the furnace contained 140 pounds of A380. Natural gas use was 5.2 cubic feet/lb or $5228 \mathrm{Btu} / \mathrm{lb}$. Dividing the theoretical energy to heat and melt $\mathrm{A} 380$ by the actual energy consumed by the furnace yielded overall furnace melting efficiency. Calorimetric equations were used to calculate the theoretical energy that should be required for heating A380 from room temperature to the final measured melt temperatures. The result of this particular experiment was that the overall energy efficiency of the furnace in melting A380 was $8.2 \%$. This type of experiment was conducted on several occasions with similar results, although melting efficiency increased when the furnace crucible was filled closer to capacity with molten alloy.

Many small die-casters use gas-fired crucible furnaces like the one studied in the OSU audit because of their flexibility in quickly changing to different casting alloys. Crucible furnaces may not be as energy efficient as other types, but other types can typically be dedicated to only one casting alloy. Table 3 shows a comparison of expected energy consumption for common furnace types. Significant additional reductions in energy consumption (up to $30 \%$ ) may also be obtained with gas-fired furnaces equipped with heat recuperation or regeneration systems [4].

Another important consideration in the selection of melting equipment for aluminum is metal loss due to oxidation. Gas-fired furnaces typically cause more oxidation and dross of aluminum than do electric furnaces. Metal loss can be a significant cost consideration in high production die-casting facilities.

\section{Table 3. Expected Energy Consumption and Percentage Metal Loss of Furnace Types for Melting Aluminum Alloys [2]}

\begin{tabular}{|l|l|l|l|l|}
\hline Gas Crucible & Gas Dry Hearth & Gas Reverb & $\begin{array}{l}\text { Electric } \\
\text { Reverb }\end{array}$ & $\begin{array}{l}\text { Electric } \\
\text { Induction }\end{array}$ \\
\hline $3500 \mathrm{Btu} / \mathrm{lb}$ & $2500 \mathrm{Btu} / \mathrm{lb}$ & $1500 \mathrm{Btu} / \mathrm{lb}$ & $785 \mathrm{Btu} / \mathrm{lb}$ & $853 \mathrm{Btu} / \mathrm{lb}$ \\
\hline $3 \%$ metal loss & $6 \%$ metal loss & $3 \%$ metal loss & $1 \%$ metal loss & $1.5 \%$ metal loss \\
\hline
\end{tabular}

Although the electric furnaces (reverb and induction) are more energy efficient on-site, the cost of electricity in terms of $\$$ Btu is historically about 3 times that of natural gas. This is due to the conversion cost of generating electricity from other fuels. Based on the 
survey respondents, the cost of electricity reported was $\$ 0.04 / \mathrm{KWH}$ which equates to about $1.7 \times 10^{-5} \$ / B t u$, using a conversion of $1 \mathrm{KWH}=3412 \mathrm{Btu}$. The cost of natural gas was reported as $\$ 5 / \mathrm{MCF}$ ( $\mathrm{MCF}=1000$ cubic feet) which equates to $0.5 \times 10^{-5} \$ / \mathrm{Btu}$, using a conversion of 1 cubic foot of gas $=1000 \mathrm{Btu}$. Therefore, the 3:1 ratio of electricity cost to natural gas cost per energy unit remains a good estimate.

\subsection{Energy Audits: Energy Consumed in the Form of Electricity}

Table 3 indicates the amount of energy expected for melting aluminum in a hot furnace, in most cases with a molten heel (wet bath). However, during off-shifts, weekends, and holidays, the melting or receiving furnaces serve the function of holding furnaces. Also, the holding furnaces at each die-casting machine remain on 24 hours per day, 7 days a week. Energy must be expended in all of these furnaces to replace heat lost through furnace walls, dip-wells, exhaust stacks, and other openings.

Data were collected from the DC2 facility electric utility meter located in the sub-station exclusively serving the 2 receiving-holding furnaces of 90,000 pounds each. The metered electrical energy used by both furnaces together in the month of August 2002 was $245,000 \mathrm{KWH}$. This equates to $6.3 \mathrm{Btu} / \mathrm{lb} / \mathrm{hr}$. It should be noted that these furnaces are not typically used for melting, only receiving molten metal via truck delivery and holding metal during off-production times. Molten metal poured into the furnaces from the metal delivery trucks is often at a higher temperature than the target furnace hold temperature.

An electric power meter was procured with project funds (POWERLOGIC ${ }^{\circledR}$ EME 3021 Energy Meter) and deployed at the DC2 die-casting facility for the measurement of electrical energy consumed by 2 die-casting machine holding furnaces. One holding furnace (A1) was a commercial design that had recently been refurbished, and the other (B7) was a new custom designed furnace. Both were electric resistance (radiant, not immersion) furnaces of 4,000-pound capacity. Table 4 shows the energy used for holding during production and during off-production times for furnaces A1 and B7. These data were collected over a 2-week period.

Table 4. Electrical Energy Use for DC2 Electric Holding Furnaces A1 and B7.

\begin{tabular}{|c|c|c|c|c|}
\hline Furnace & $\begin{array}{c}\text { Average KW } \\
\text { During Production }\end{array}$ & $\begin{array}{c}\text { Average KW } \\
\text { Off-Production }\end{array}$ & $\begin{array}{c}\text { Overall Average } \\
\text { KW }\end{array}$ & $\begin{array}{c}\text { Average } \\
\text { BTU/lb/hr }\end{array}$ \\
\hline A1 & 44.3 & 29.9 & 39.8 & 34.0 \\
\hline B7 & 34.1 & 25.0 & 32.6 & 27.8 \\
\hline
\end{tabular}

The B7 furnace design was a significant improvement (18\%) over the A1 design. Specific design improvements included the use of a more efficient resistance heating device, a new charge door design that prevented heat loss better when closed, and a dip well design that minimized the area of molten aluminum exposed to air. Also, the reason 
that energy consumption dropped significantly during off-production times for both furnaces is that the dip wells were covered with insulating doors when production ceased. Die-casting machines and related equipment for the actual casting process also consume electrical energy. As a component of this project, another electrical power meter (Fluke ${ }^{\circledR}$ 43B Power Quality Analyzer) was deployed on the main electrical feed to an 800 ton diecasting machine cell at the DC1 facility. The cell included the die-casting machine, an overhead spray device (reciprocator), an automatic ladler, an articulated arm extractor robot, and a conveyor to transport castings to the trim press. Table 5 shows the energy consumption measured and casting cycles for this die-casting machine cell for one complete 8-hour shift on March 25, 2003.

Table 5. Die-Casting Machine Cell Energy Consumption at DC1 Facility

\begin{tabular}{|c|c|c|c|}
\hline $\begin{array}{l}\text { Average KW } \\
\text { During Production }\end{array}$ & $\begin{array}{l}\text { Average KW } \\
\text { During Idle Time }\end{array}$ & $\begin{array}{l}\text { Overall Average } \\
\text { KW During Shift }\end{array}$ & $\begin{array}{l}\text { Machine Cycles } \\
\text { During Shift }\end{array}$ \\
\hline 23.7 & 11.1 & 19.5 & 393 \\
\hline
\end{tabular}

The casting cell experienced approximately 2 hours of idle time during this shift due to equipment problems downstream. When the casting cell was operating non-stop in production mode it consumed energy at a rate of $80,864 \mathrm{Btu} / \mathrm{hr}$.

Table 6 is a summary of energy consumption for specific die-casting operations based on the literature available and metered energy audits at the OSU, DC1 and DC2 die-casting sites.

Table 6. Energy Consumption Summary for Aluminum Cold Chamber Die-Casting

\begin{tabular}{|l|l|l|}
\hline Operation & $\begin{array}{l}\text { Type and Size of Equipment } \\
\text { Considered }\end{array}$ & $\begin{array}{l}\text { Energy Consumption } \\
\text { Estimate and Metric }\end{array}$ \\
\hline Melting & $\begin{array}{l}70,000 \text { lb capacity gas-fired } \\
\text { reverb furnace (no recuperation } \\
\text { or regeneration) capable of } \\
\text { melting } 6000 \text { pounds per hour }\end{array}$ & $\begin{array}{l}1500 \mathrm{Btu} / \mathrm{lb} \text { of alloy } \\
\text { melted (or 9,000,000 } \\
\text { Btu/hr during full } \\
\text { casting production) }\end{array}$ \\
\hline $\begin{array}{l}\text { Central Receiving/Holding } \\
\text { of Molten Alloy }\end{array}$ & $\begin{array}{l}90,000 \text { lb capacity electric } \\
\text { resistance reverb furnace }\end{array}$ & $\begin{array}{l}10 \mathrm{Btu} / \mathrm{hr} / \mathrm{lb} \text { of alloy } \\
\text { held at temperature (or } \\
900,000 \text { Btu/hr of } \\
\text { furnace operation) }\end{array}$ \\
\hline $\begin{array}{l}\text { Holding Alloy at Die- } \\
\text { Casting Machine }\end{array}$ & $\begin{array}{l}4000 \text { lb capacity electric } \\
\text { resistance radiant heat furnace }\end{array}$ & $\begin{array}{l}30 \mathrm{Btu} / \mathrm{hr} / \mathrm{lb} \text { of alloy } \\
\text { held at temperature (or } \\
120,000 \mathrm{Btu} / \mathrm{hr} \text { of } \\
\text { furnace operation) }\end{array}$ \\
\hline Die-Casting Machine Cell & $\begin{array}{l}800 \text { ton automated cell in full } \\
\text { production mode }\end{array}$ & $\begin{array}{l}81,000 \mathrm{Btu} / \mathrm{hr} \text { of actual } \\
\text { casting production }\end{array}$ \\
\hline
\end{tabular}




\subsection{Energy Models}

Two modeling approaches were developed concurrently in this project. The first model described in this report is based on Absorbing State Markov Chains (ASMC) and has been named The Energy Assessment Model (TEAM). This model was developed as a tool for use at the individual die-casting enterprise level for assessing the impact of process or equipment changes on energy consumption. The resulting model is relatively simple and was developed in an Excel spreadsheet. The goal of TEAM is to provide managerial insight into the causes of energy consumption beyond the obvious causes and the factors of production that affect that consumption. The second model described is a more complex dynamic model which is capable of assessing temporal changes in diecasting systems on energy consumption. A commercially available software package, iThink $^{\circledR}$ version 6.0.1, a dynamic system simulation software was selected for this application [6]. This model can be used either at the individual die-casting enterprise level, or at the macroscopic level from bauxite extraction to casting end use or recycling.

\subsubsection{The Energy Assessment Model (TEAM)}

The purpose of TEAM is to do a ground-up calculation of energy consumption in a die casting facility, rather than a top-down assessment based on aggregate production quantities. One advantage of the TEAM approach is that when two facilities differ substantially in energy usage per pound of finished casting, TEAM makes it possible to discover the sources of the discrepancies. A second advantage is that TEAM can be used to evaluate the impact on energy consumption in "what if" scenarios thereby enabling facility management to make more energy conscious decisions.

The TEAM model overview is depicted in figure 2. The workhorse of TEAM is an absorbing Markov chain which tracks the flow of the casting material as it circulates and re-circulates through the facility until it finally ends up in a finished casting. Given the number of pounds of finished castings, the weight of castings before and after machining, yield, scrap, and dross rates; the Markov model calculates the amount of casting material that would need to be bought, the number of pounds of scrap melted the and the number of shots required. To categorize these input data the Markov model is primarily driven by product specific information.

The second component of TEAM is an energy accounting model, which receives input from the Markov model as well as information about the overall facility configuration and energy consumption measurements on machines. These data on configuration include such information as holding capacity, number of die-casting machines, cycle times, and production schedules. The energy accounting model, based on information from the Markov model, number of machines, cycle times and production schedules, and the number of calendar days needed to produce the given number of pounds of finished castings. Finally, the energy consumption measurements, which are in terms of rates, are applied to the number of calendar days, number of shots, number of pounds melted, furnace capacity and the number of machines, in order to estimate the energy consumption. 


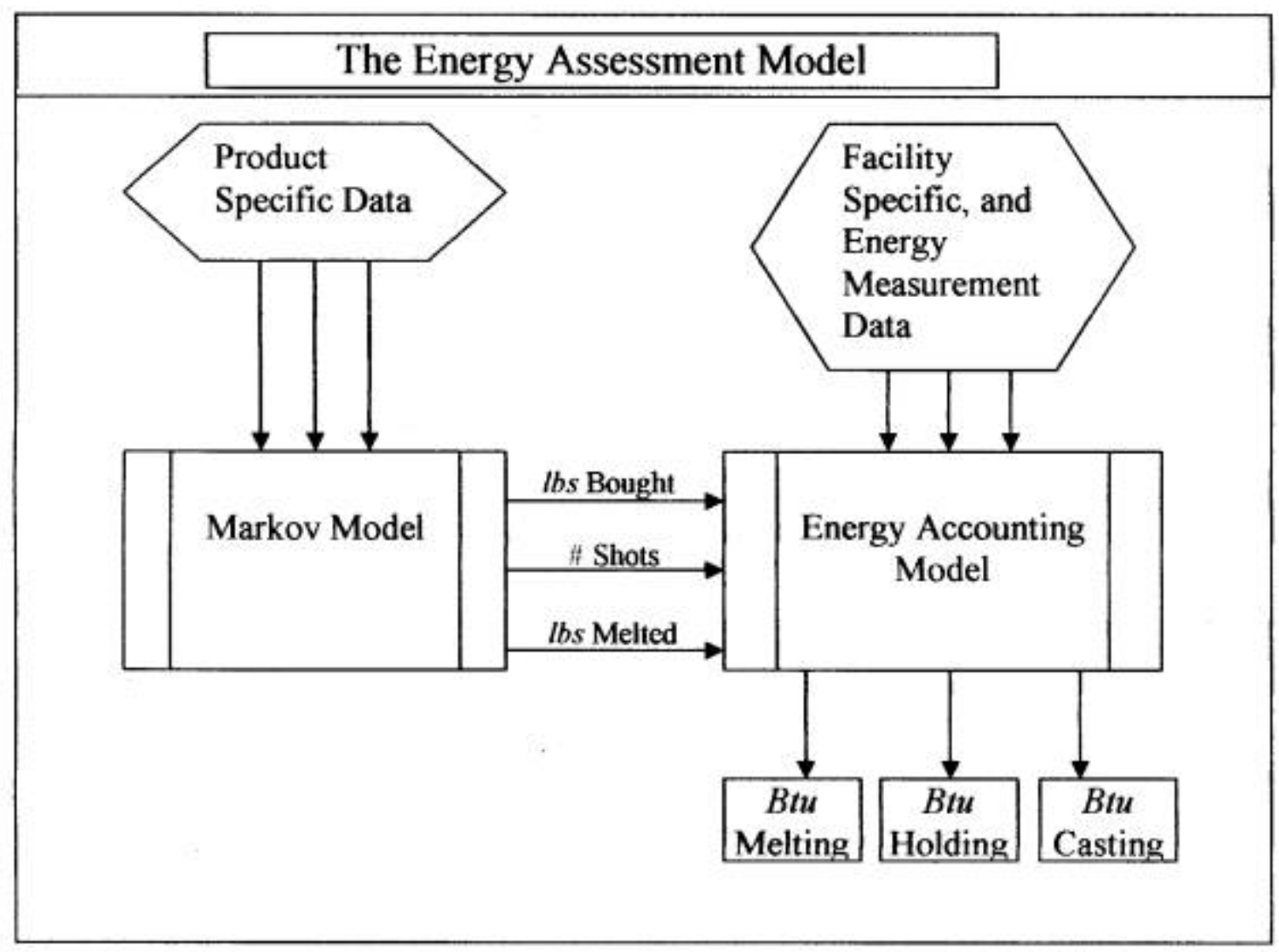

Fig. 2. Schematic of the energy assessment model

Figure 3 shows a view from TEAM Excel spreadsheet results for one month time frame at DC2. In this case, Sold Dross, Sold Scrap, and Finished Product are the three absorbing states. As alloy enters the system it moves from block to block in the diagram with probability indicated by the percentage labels (yellow) on the movement arrows. The quantities in the major blocks (red) are the pounds of alloy (times 1000) that pass through that stage of the process. For example, the model shows that if 4,585,000 pounds of alloy finished product are to be sold per month (blue model input value), 5,448,000 pounds of alloy must be purchased for input to the process, which will require 9,075,000 pounds of alloy to be melted and held until cast, including 3,627,000 pounds of re-melted alloy recycled from the process. The percentages above the top row of major boxes have various interpretations. In particular, the $119 \%$ on the first box indicates that $19 \%$ more alloy is purchased than ends up in finished product. $198 \%$ on the second box indicates that almost twice as much alloy is melted and held than ends up as finished product. The $114 \%$ on the third box indicates that $14 \%$ more die-casting machine cycles are made than the minimum needed to produce the finished product.

The model shows that almost twice as much alloy passes through the shop than ends up in finished product. The $106 \%$ on the remaining three blocks indicate that $6 \%$ more product units are cooled, trimmed, checked and machined than end up as finished products. The model also indicates that for this particular die-casting plant quality checks (QC) before machining are made at the die-casting machine rather than at a separate QC 
station, but the model is flexible enough to accommodate a shop which does the separate QC or does QC at both the machine and prior to machining. Although not shown, with appropriate energy consumption input data for pertinent equipment in the model, TEAM will output the energy consumption and number of die-casting machines required to meet desire production output. Using this ground-up approach, TEAM estimated the energy consumption at the DC2 enterprise to be $2200 \mathrm{Btu} / \mathrm{lb}$, considering only the energy required to melt, hold, and die-cast. Adding in the energy consumption "overhead" for the rest of the plant operations (light, heat, compressed air, etc.) yielded a total of 3600 $\mathrm{Btu} / \mathrm{lb}$, which is very close to what was reported in the survey for DC2 (3744Btu/lb).

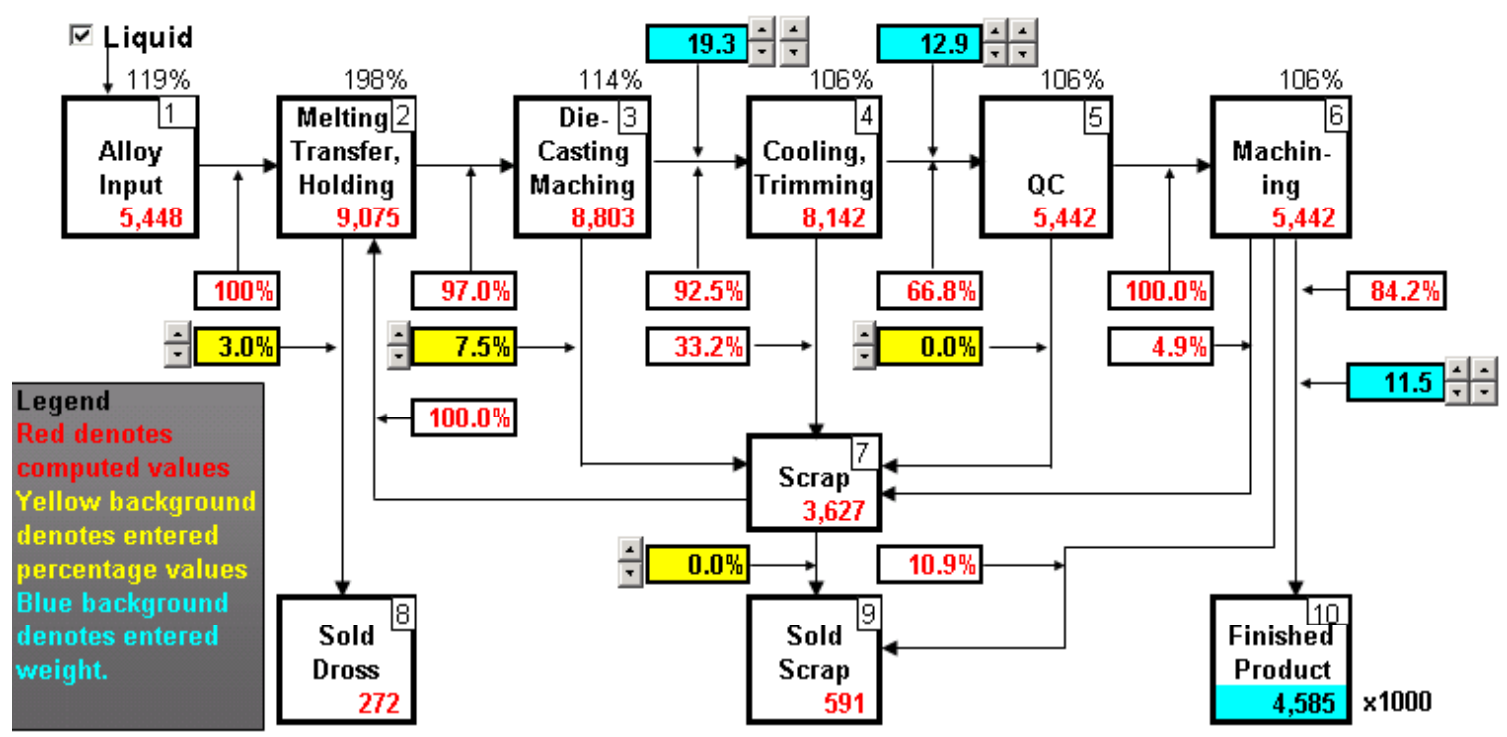

Figure 3. The TEAM Absorbing State Markov Chain Model for DC2

In summary, TEAM was developed as a tool to quickly evaluate the influence on energy consumption of changes in enterprise parameters such as casting yield, scrap rate, machine stock removed, type of furnace, furnace efficiency, production rate, and the purchase of liquid alloy versus solid ingot.

\subsubsection{The iThink ${ }^{\circledR}$ Dynamic Model}

A dynamic energy model was created based on the flow chart shown in Appendix B. The overall process, which is the process from bauxite to landfill, was modeled using iThink ${ }^{\circledR}$ and was described in the DOE second year annual report. The die-casting enterprise level simulation model is the main part of the overall system model and will be described here. The purpose of the model is to establish the relationship between all of the various energy inputs and operational efficiencies in the die-casting system. The model enables users to perturb any of the energy inputs or efficiencies, and observe (quantitatively) what the net result on the entire energy system will be as a function of time. The concept was to create a tool for evaluating the "energy journey" in die-casting systems by evaluating the influence of increasing or decreasing the energy use or efficiency of various diecasting operations as a function of time. 
The die-casting enterprise level dynamic model consists of 5 process stages: 1) melting, 2) holding, 3) die casting, 4) trimming, and 5) machining. These model stages are shown graphically in figures 3-9. In the melting process, solid ingots and the available scrap for recycle are melted and directed to the holding furnace where the melted metal is kept at a certain degree. From the holding furnace, the melted metal is ladled into the die casting machine. Die casting machine produces castings and scrap. The scrap might be sold or recycled or a combination of these two. The castings are then directed to the trimming process. After the trimming process, the castings which pass the quality control test will go to the machining process. The output of the machining process is final castings and scrap. Once the energy consumption is determined for each stage of the model, the data is integrated into a metric of total energy consumption.

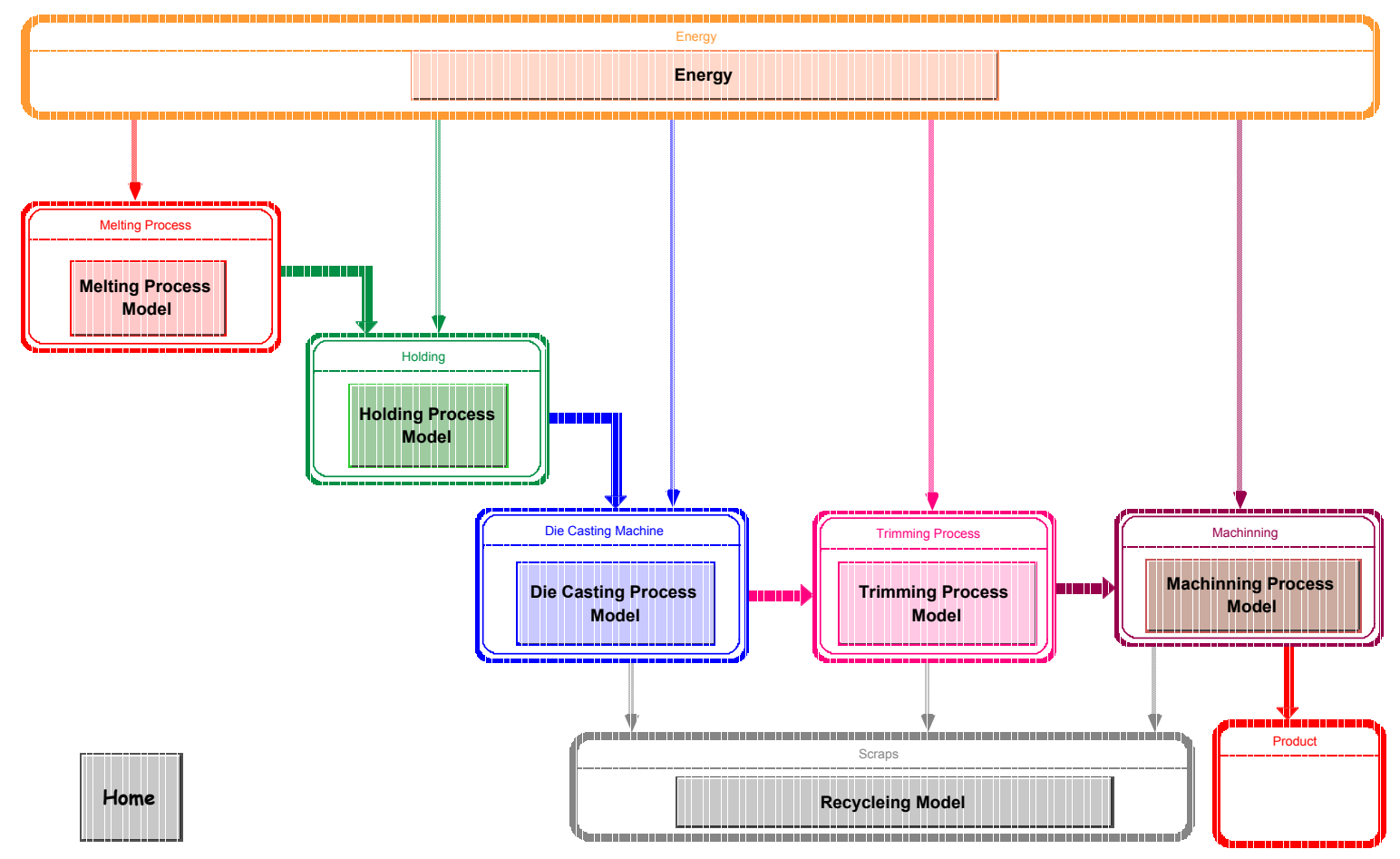

Figure 3. Overview of the die casting process enterprise level iThink ${ }^{\circledR}$ model. 


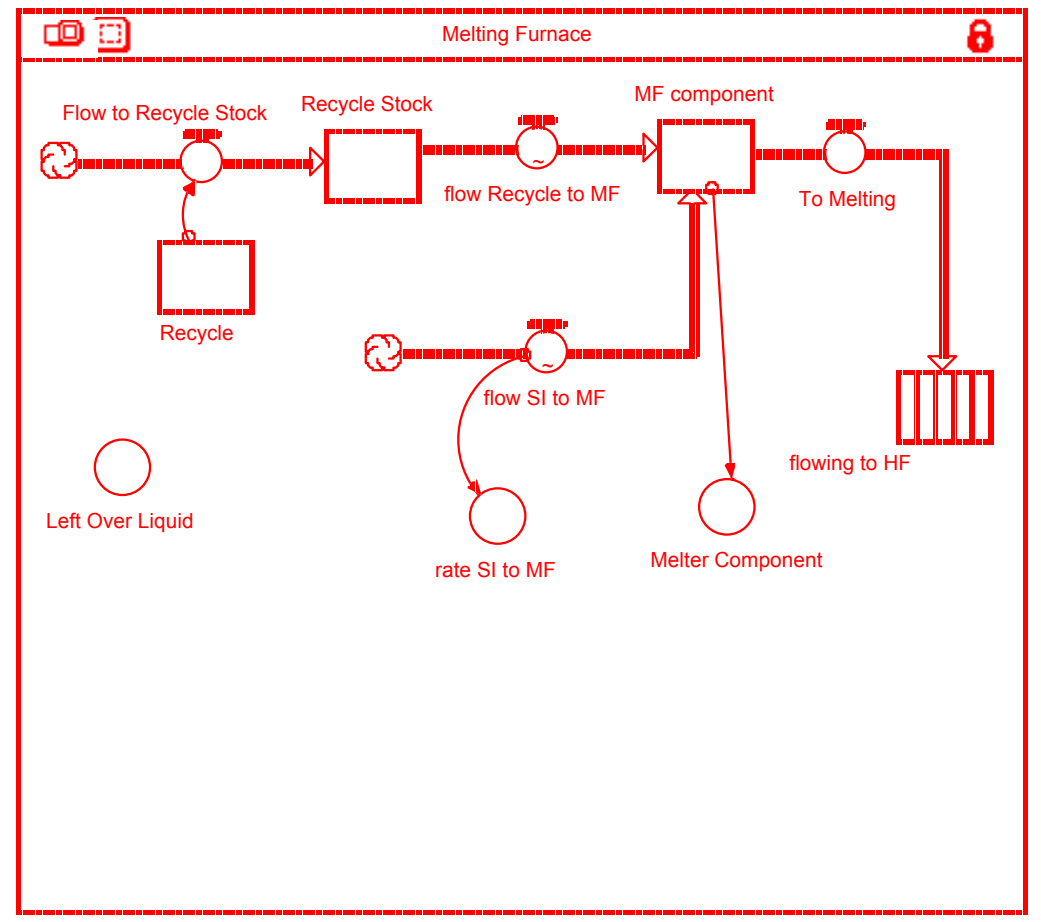

Figure 4. The first stage melting process, where MF indicates melting furnace, $\mathrm{HF}$ indicates holding furnace, and SI indicates solid ingot.

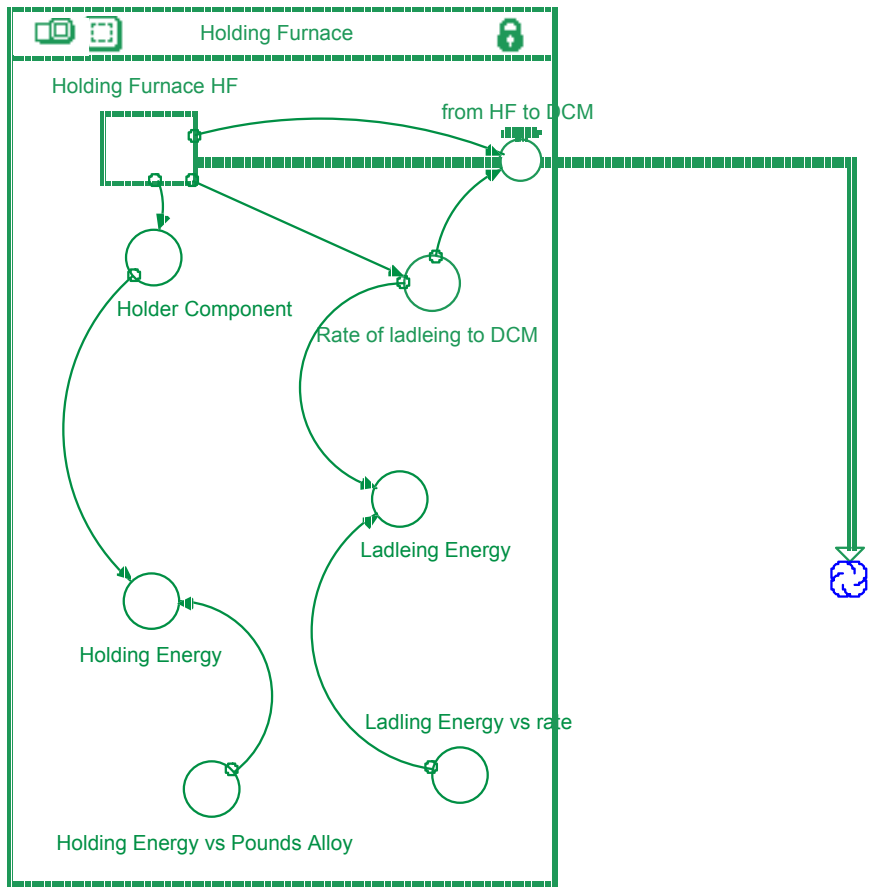

Figure 5. Representation of the second stage of the process model, holding. 


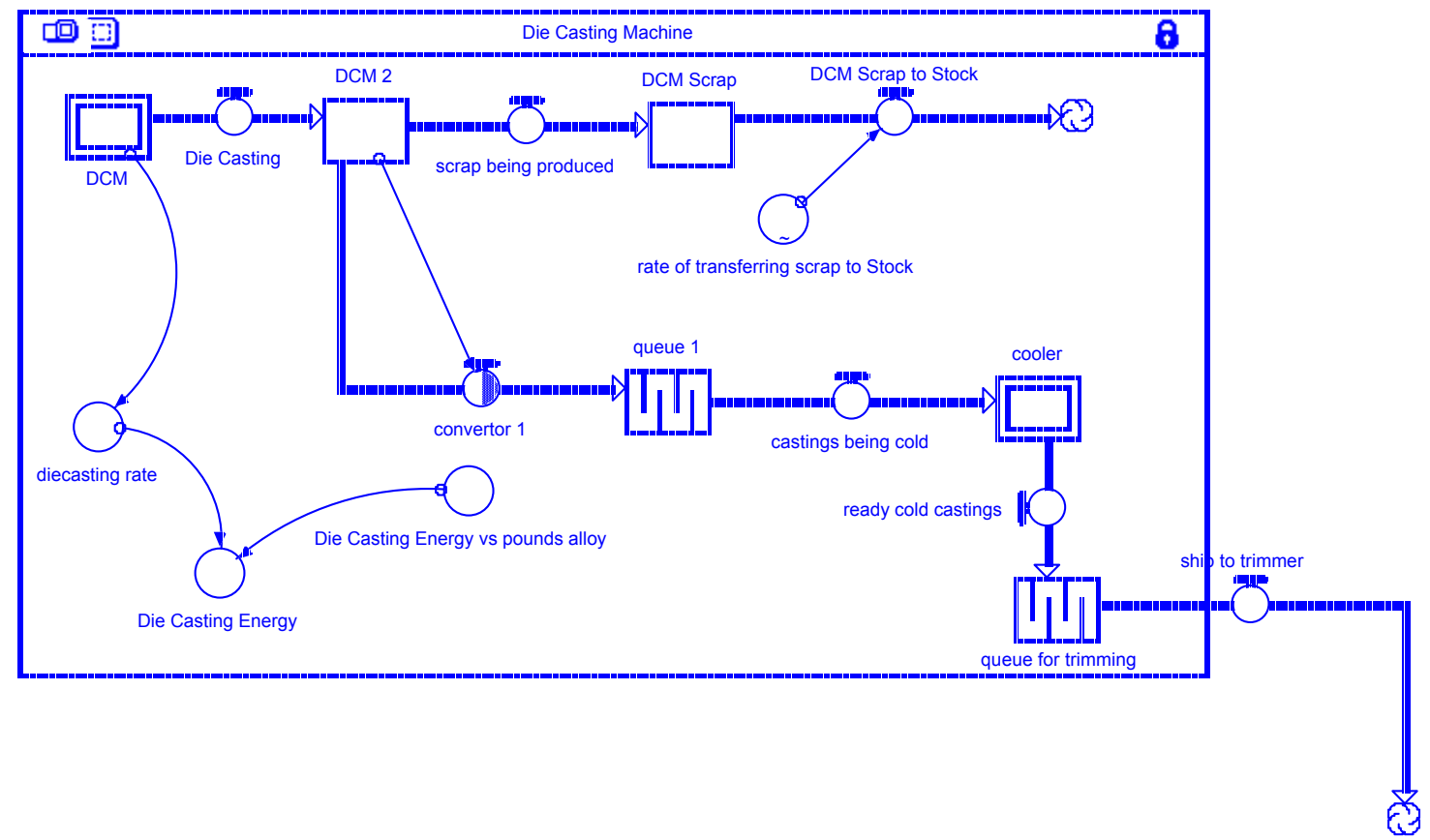

Figure 6. The third stage in the model is the actual die casting process.

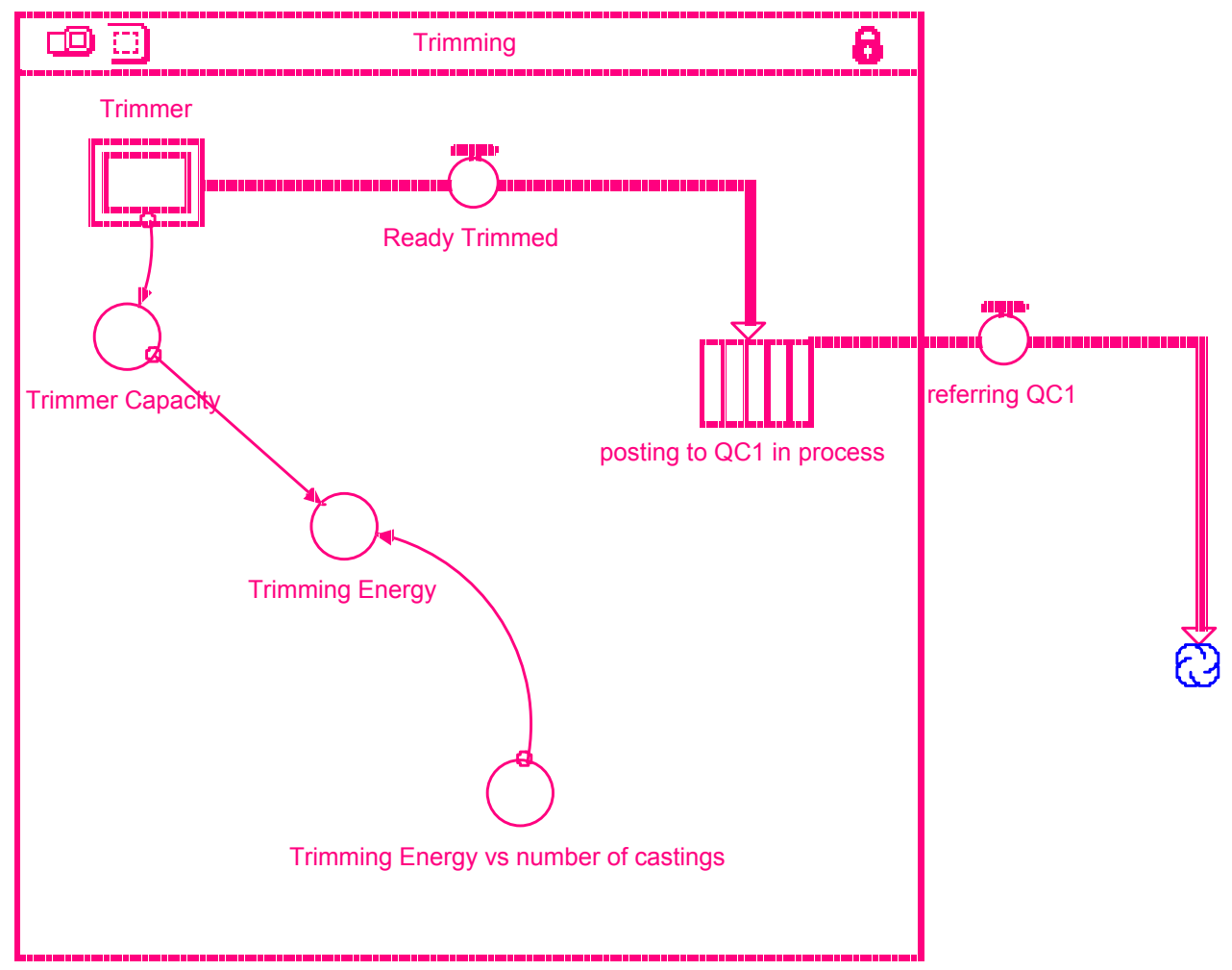

Figure 7. The fourth stage of the process is trimming; QC indicates quality control. 


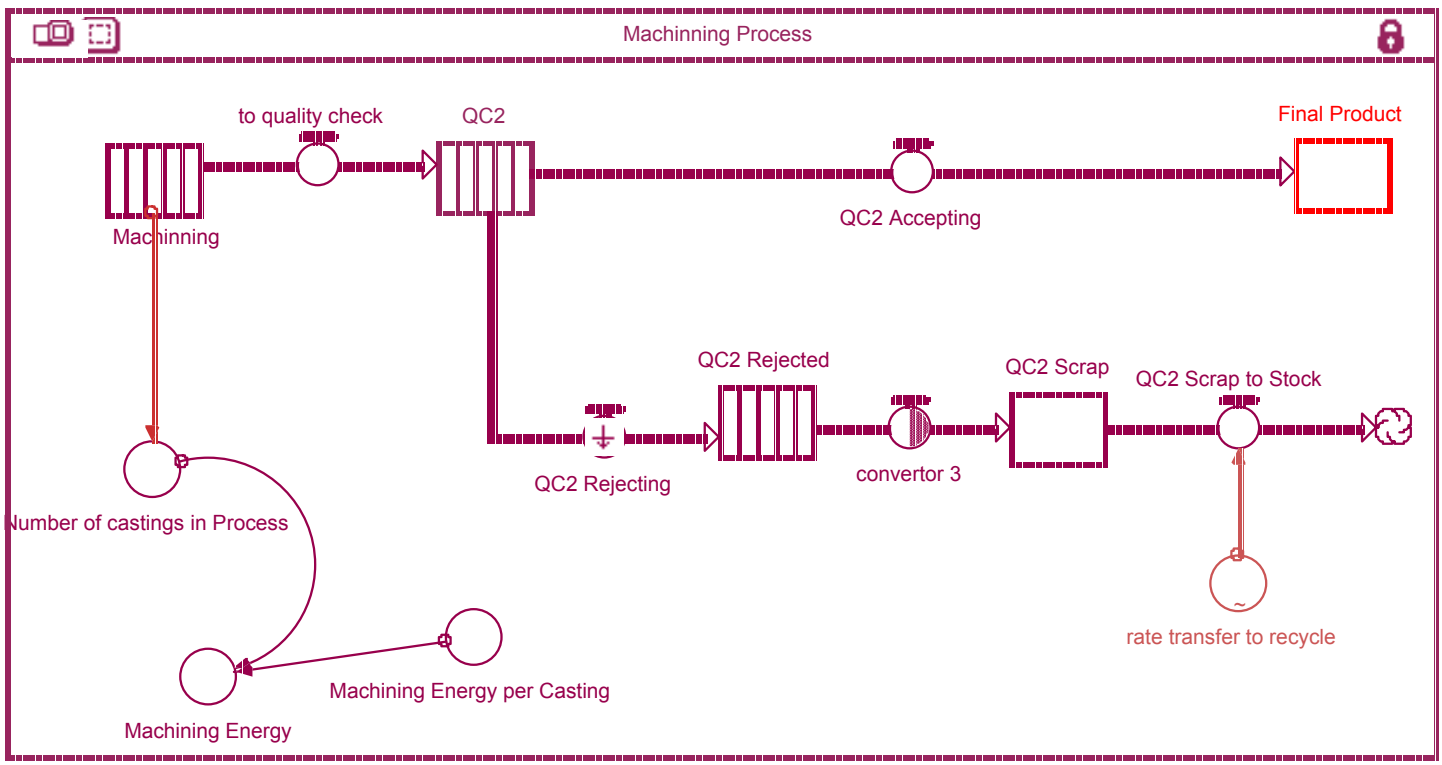

Figure 8. The fifth and the last stage of the process, machining and final QC.

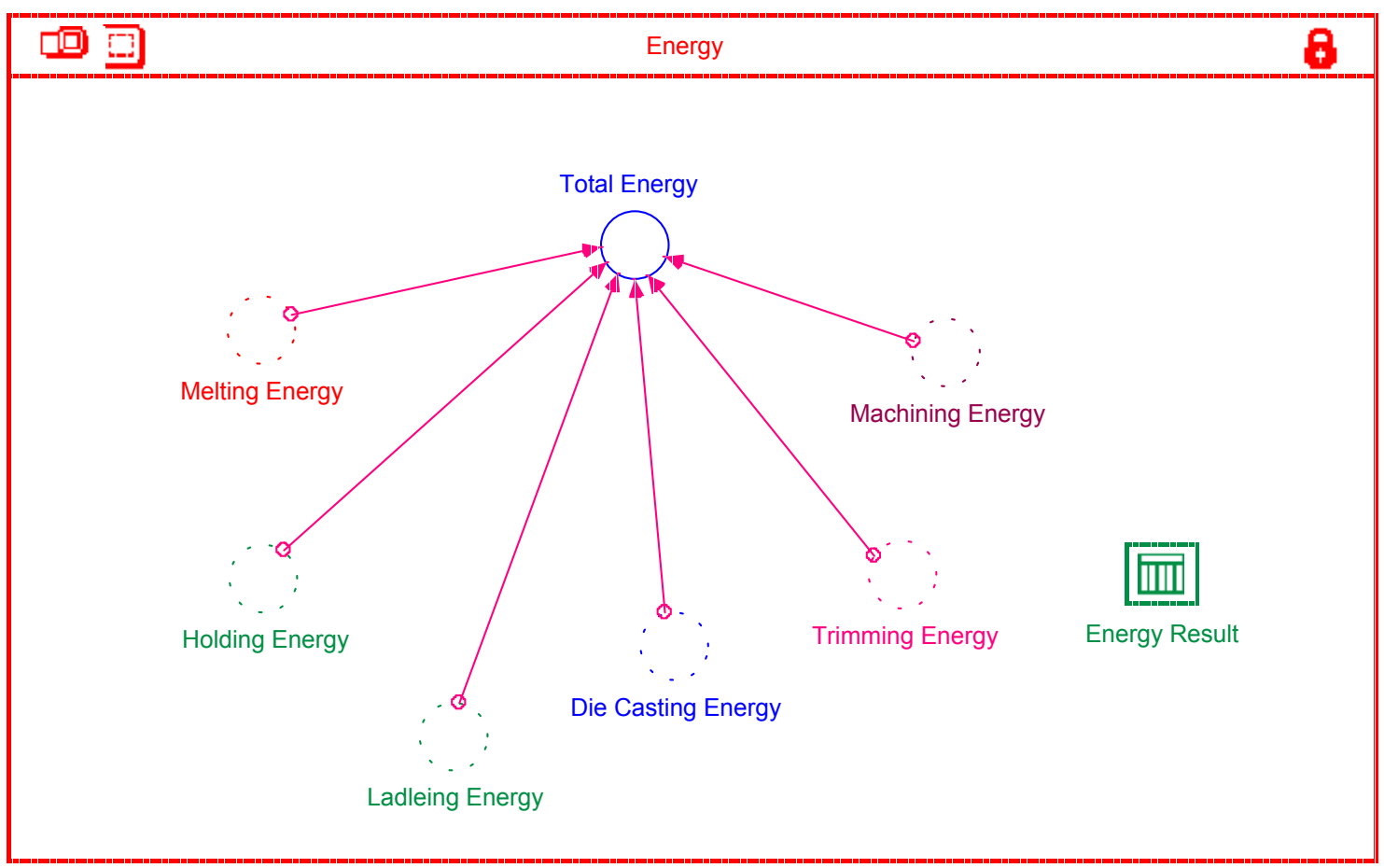

Figure 9. As shown here, in order to compute the total energy of the process, the consumed energy at all the stages are combined. 
At each stage of the model, the required energy can be calculated, given that the required energy input data are available. Required data inputs for the iThink ${ }^{\circledR}$ model are the following:

\section{Melting Furnace}

- Rate of liquid alloy and solid ingots to the melting furnace

- Rate of reused scrap to melting furnace

- Efficiency of the melting furnace

- Rate and percentages of liquid alloy and dross coming out of the melting furnace

\section{Holding furnace}

- Rate of entering ladle into the holding furnace

- Efficiency of the holding furnace

- Rate of liquid alloy entered to the holding furnace

- Rate of liquid alloy, scrap and dross coming out of the holding furnace

\section{Die Casting Machine}

- Rate of liquid alloy to die casting machine

- Number of shots per unit of time

- Number of castings per shot

- Percentages of castings and scraps coming out of the die casting machine

- Amount of energy required for one shot

\section{Trimming}

- Rate and percentages of produced castings and trimmings

- Rate of energy required for trimming

\section{Quality Check}

- Percentage of rejected castings

\section{Machining Process}

- Percentage of final accepted product

- Percentage of ruined castings

- Rate of energy required for machining

\section{Scrap}

- Rate of sold scrap

- Rate of reused scrap

In summary, the iThink $^{\circledR}$ dynamic model is potentially more powerful than the TEAM model, because it is a more comprehensive model that can evaluate systems as a function of time. However, the iThink ${ }^{\circledR}$ model requires possession of the software, and much more detailed input data to function properly. 


\subsection{Conclusions}

A literature review regarding energy use in die-casting was conducted and yielded pertinent information regarding energy consumption of melting and holding furnaces used for die-casting. An energy survey instrument was developed, distributed to North American Die Casting Association (NADCA) corporate members, and the data collected and analyzed. It was determined that the amount and quality of energy data available in the die-casting industry is generally poor. Using data from the literature and survey an accurate flow chart for mapping energy inputs for the die-casting industry was developed.

The relative importance of various energy-consuming operations in die-casting such as alloy melting, alloy holding, and die-casting were determined via energy audits conducted at the OSU die-casting laboratory and at industry sites. Based on the information derived from the energy survey and on-site energy audits, the computerbased models TEAM and iThink ${ }^{\mathbb{B}}$ were developed. These models allow the energy "journey" in die-casting operations to be assessed.

Both the TEAM ASMC and iThink $^{\circledR}$ models can be applied to individual plants or industry aggregates although some analysis is needed to see if aggregation introduces any significant systematic bias into the estimates that come from the models. ASMC model does not directly capture the dynamic effects of time as will the I-Think model. However, once the dynamic effects are well understood, it may be possible to incorporate them in the spreadsheet with the TEAM model.

In summary, the overall objective of this research project, to develop models for diecasting operations that can be used to assess the influence of equipment or process changes on energy consumption, has been accomplished.

\subsection{Project Reporting and Student Participants}

Oral reports of the project activities were presented and reviewed at the following North American Die Casting Association (NADCA) Committee and local Chapter meetings:

\begin{tabular}{|c|c|c|}
\hline NADCA Committee/Group & Meeting Date & Meeting Place \\
\hline $\mathrm{R} \& \mathrm{D}$ meeting & $2 / 7 / 2001$ & NADCA, Illinois \\
\hline R\&D meeting & $6 / 20 / 2001$ & OSU, Columbus, $\mathrm{OH}$ \\
\hline R\&D meeting & $1 / 24 / 2002$ & NADCA, Illinois \\
\hline$R \& D$ meeting & $6 / 12 / 2002$ & $\begin{array}{l}\text { Case Western Reserve } \\
\text { University, Cleveland, } \mathrm{OH}\end{array}$ \\
\hline R\&D meeting & $1 / 23 / 2003$ & NADCA, Illinois \\
\hline R\&D meeting & $10 / 16 / 2003$ & NADCA, Illinois \\
\hline Milwaukee Chapter & $1 / 28 / 2004$ & Milwaukee, WI \\
\hline
\end{tabular}

An oral presentation and technical project review was also conducted at the FY2003 DOE/CMC Metalcasting IOF Portfolio Review in Chicago, IL, October 14-15, 2003. 
Three OSU graduate students worked on various aspects of this project. Mr. Rahul Kochhar, worked on the experimental determination of the energy use in melting aluminum. Rahul is working toward his M.S. Degree requirements in Industrial and Systems Engineering (ISE). He is currently employed as a graduate student intern at SPX Contech in Auburn, IN. Mr. Shardul Phadnis assisted in the conduct of melting energy and die casting machine energy monitoring at die casting industry partner sites. He has completed his MS degree in ISE and is employed as an engineering manager for Russell William Ltd., Odenton, MD. Ms. Laila Haerian is continuing her graduate studies pursuing a Ph.D. Degree in ISE. Laila worked with both Rahul and Shardul to collect energy data and also was responsible for the iThink dynamic modeling approach in this research.

\subsection{Acknowledgements}

Throughout this project, the 2 survey responding die-casters were extremely helpful during follow-up visits to their facilities. Their cooperation in the conduct of energy metering of their equipment was outstanding. Their inputs and insights were also invaluable during the development of the models. In addition, the NADCA staff was very helpful in providing their Corporate Member Directory and offering CD's and books as incentives to survey respondents.

\subsection{References}

[1] Metalcasting Industry Technology Roadmap, January 1998, p.28.

[2] Kennedy, S., "Fossil Fuels or Electric - How Should You Melt?", Paper No. G-T79$075,10^{\text {th }}$ SDCE International Die Casting Exposition \& Congress, St. Louis, MO, March 19-22, 1979.

[3] Charnes, A., Cooper, W., Lewin, A., and Seiford, L., Data Envelopment Analysis; Theory, Methodology and Applications, Kluwer Academic Publishers, Boston, MA, 1994, ISBN 0-7923-9479-8.

[4] Golany, B., Roll, Y., Rybak, D., "Measuring Efficiency of Power Plants in Israel by Data Envelopment Analysis", Transactions on Engineering Management, Vol. 41, No. 3, August, 1994, pp. 291-301.

[5] Woodward, R., and Young, S., "Energy Conservation in Aluminum Melting with the CerHx Recuperator", Paper No. G-T85-012, SDCE $13^{\text {th }}$ International Die Casting Exposition \& Congress, Milwaukee, WI, June 3-6, 1985.

[6] iThink is a registered trademark of High Performance Systems, Inc., 45 Lyme Road, Suite 300, Hanover NH 03755, Phone: 603-643-9636. 
Appendix A

Energy Survey 


\section{To Whom It May Concern:}

A team of researchers at the Ohio State University is conducting a study for and in cooperation with the North America Die Casting Association (NADCA). The study is funded by the U. S. Department of Energy. The purpose of the study is to compile and model information about energy consumption in the die casting energy. Anticipated outcomes will be (1) information that die-casting plant managers can use to benchmark their plant's energy consumption, and (2) recommendations of effective strategies and decision tools for reducing energy costs.

As a NADCA member your plant is an important part of this study, and we request your participation in a survey by completing the enclosed questionnaire. Included with the questionnaire is a general flow chart of typical die-casting processes. The chart is labeled with large capital letters at various points. The labels on the chart are used in the questionnaire as a cross reference to help you understand the questions that may be expressed in non-standard terminology.

The information you provide will be kept in strict confidence and as soon as it is feasible to do so the name of your organization will be completely disassociated from the data you have provided. Survey results will be provided to all survey participants.

Before you start completing the questionnaire or any time thereafter please feel free to contact either of the following two researcher for assistance, or clarification.

$\begin{array}{rll} & \text { Dr. Jerry Brevick } & \text { Dr. Clark Mount-Campbell } \\ \text { E-mail: } & \text { brevick.1@osu.edu } & \text { mount-campbell.1@osu.edu } \\ \text { Telephone: } & \text { (614) 292-0177 } & \text { (614) 292-7856 } \\ \text { Fax: } & \text { (614) 292-7852 } & \text { (614) } 292-7852\end{array}$

Thank you for your assistance in this matter.

Sincerely,

Steve Udvardy,

Technical Director NADCA

Jerry Brevick, Ph. D., P.E.

Co-Principal Investigator

Clark Mount-Campbell, Ph. D.

Co-Principal Investigator 


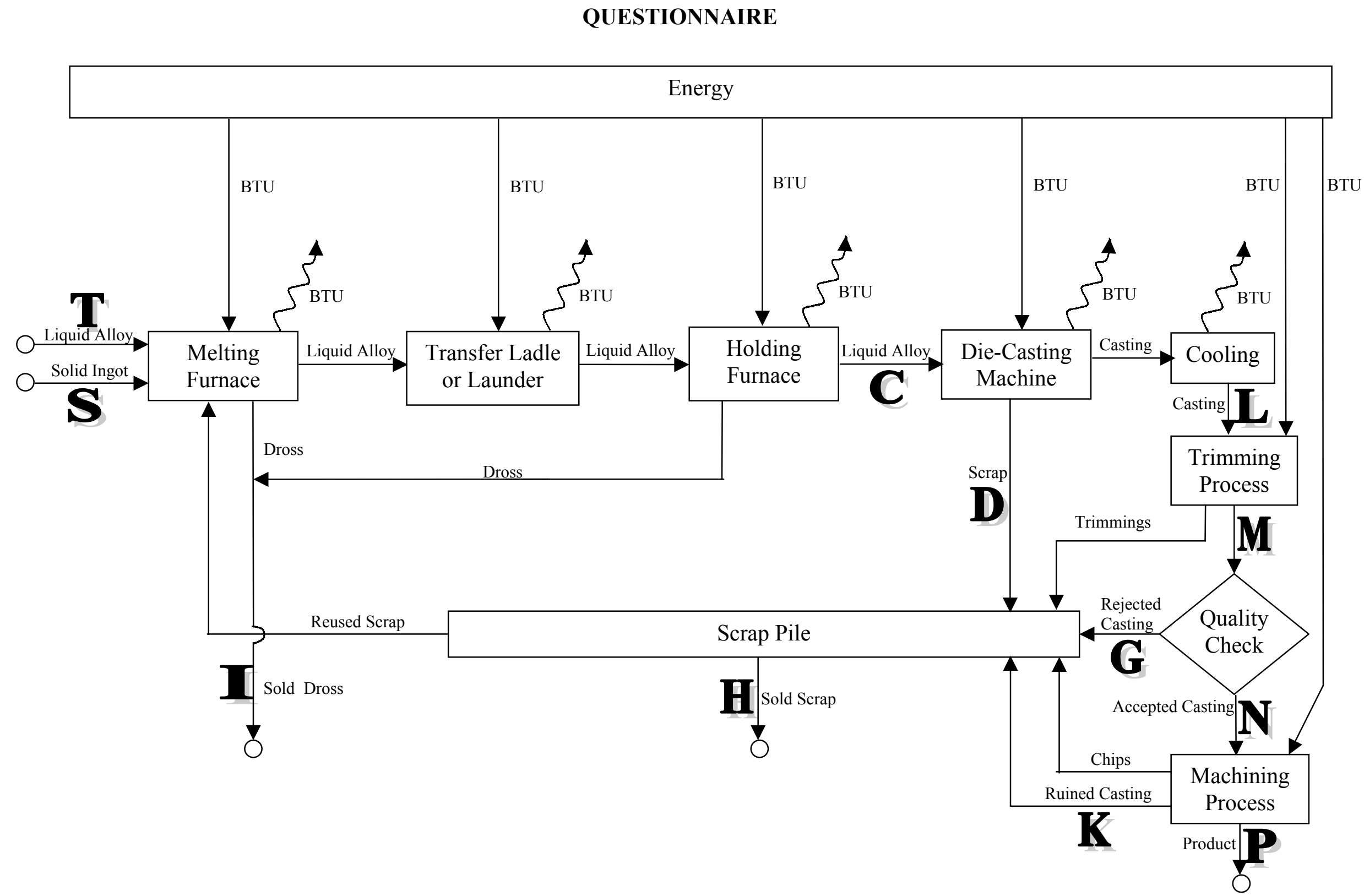


1. Please provide contact information in the event the research team needs clarification on question responses.

Name: , E-mail:

Telephone:

2. The next four questions ask about input and output production quantities, scrap, and energy consumption over a time period. Since we are not familiar with the timing of your company's information reporting systems we would like you to choose the time frame that is convenient for you. Our only request is that you choose a time period that is as recent as possible and as long as possible up to one year. Please choose the time period that will apply to the responses in the next four questions:

From: to: for a total of: months.

3. Please indicate total production shipped (by alloy) in the reporting period you chose above by filling in the cells relevant to your operation with the gross weight of all castings produced in the period. Please include units of measure.

\begin{tabular}{|c|c|c|c|c|c|c|}
\hline & \multirow{2}{*}{$\begin{array}{c}\text { Chart } \\
\text { Reference } \\
\text { Letter }\end{array}$} & \multirow[b]{2}{*}{ Al } & \multirow[b]{2}{*}{ Zn } & \multirow[b]{2}{*}{ Mg } & \multirow[b]{2}{*}{$\mathbf{C u}$} & $\begin{array}{c}\text { Others } \\
\text { (Please Specify) }\end{array}$ \\
\hline & & & & & & \\
\hline $\begin{array}{l}\text { High } \\
\text { Pressure }\end{array}$ & & & & & & \\
\hline $\begin{array}{l}\text { Low } \\
\text { Pressure }\end{array}$ & D & & & & & \\
\hline Vacuum & D & & & & & \\
\hline
\end{tabular}

4. Please fill in the table below with the appropriate gross weight of alloys by type that your plant purchased for input to the casting process during the chosen reporting period.

\begin{tabular}{|l|c|c|c|c|c|c|c|}
\hline & \multirow{2}{*}{$\begin{array}{c}\text { Chart } \\
\text { Reference } \\
\text { Letter }\end{array}$} & \multicolumn{4}{|c|}{ Alloy Base Metal } & \multicolumn{2}{c|}{$\begin{array}{c}\text { Others } \\
\text { (Please Specify) }\end{array}$} \\
\cline { 3 - 8 } & Al & Zn & Mg & Cu & & \\
\hline $\begin{array}{l}\text { Received from } \\
\text { Supplier in Liquid } \\
\text { Form }\end{array}$ & $\mathbf{T}$ & & & & & & \\
$\begin{array}{l}\text { Received from } \\
\text { Supplier in Solid } \\
\text { Form }\end{array}$ & S & & & & & & \\
\hline
\end{tabular}


5. Alloy that is recycled inside your plant and outside your plant is an important component of the complete energy picture. Alloy from rejected castings, loss during setup, sprues and runners, dross, trimmings, and chips from machining are the primary source of recyclable alloy. It is known that different plants and different companies refer to scrap and measure scrap in many different ways. We are requesting the information as an average rate expressed as a percentage. Therefore, in the table below, large capital letters are provided to help explain the information being requested. For each row of requested information in the table please locate the reference letter(s) in the flow diagram to see how to calculate the requested rate. For example, the yield reference column shows $\mathbf{1 0 0} \% \times \mathbf{M} / \mathbf{L}(\mathrm{read} 100 \%$ times $\mathbf{M}$ divided by $\mathbf{L}$ ) where $\mathbf{M}$ represents the weight of castings after cooling and trimming while $\mathbf{L}$ represents the weight immediately before cooling and trimming. In other words it represents the finished casting weight (before machining) divided by the shot weight averaged over all products of an alloy.

\begin{tabular}{|c|c|c|c|c|c|c|}
\hline & & \multicolumn{4}{|c|}{ Alloy Base Metal } & $\begin{array}{l}\text { Others } \\
\text { (Please } \\
\text { Specify) }\end{array}$ \\
\hline & $\begin{array}{l}\text { Chart Reference } \\
\text { Letter }\end{array}$ & Al & $\mathbf{Z n}$ & Mg & $\mathbf{C u}$ & \\
\hline $\begin{array}{l}\text { Gross weight of } \\
\text { scrap sold }\end{array}$ & $\mathbf{H}$ & & & & & \\
\hline \begin{tabular}{|l|} 
Dross Sold or \\
Reprocessed \\
Elsewhere \\
\end{tabular} & $100 \% \times \mathbf{V}(\mathbf{T}+\mathbf{S})$ & & & & & \\
\hline $\begin{array}{l}\text { Scrap at Die } \\
\text { Casting Machine }\end{array}$ & $100 \% \times D / C$ & & & & & \\
\hline $\begin{array}{l}\text { Average Yield of } \\
\text { Castings }\end{array}$ & $100 \% \times \mathbf{M} / \mathbf{L}$ & & & & & \\
\hline $\begin{array}{l}\text { Rejected Castings } \\
\text { Before Machining }\end{array}$ & $100 \% \times \mathbf{G} / \mathbf{M}$ & & & & & \\
\hline $\begin{array}{l}\text { Rejected Castings } \\
\text { During Machining }\end{array}$ & $100 \% \times \mathrm{K} / \mathrm{N}$ & & & & & \\
\hline Machining Yield & No Chart Ref.* & & & & & \\
\hline
\end{tabular}

* Average weight of good castings after machining divided by the average weight of good castings before machining, multiplied by $100 \%$ 
6. Please fill in the table below with the gross energy input to the casting process by source during the time period chosen above. Amounts may be in physical units or monetary units. If monetary units are given please provide an estimate of the average cost per physical unit. Please indicate your best guess of the proportion of each energy source that is used exclusively for the casting operation. If the casting operation is separately metered from machining, and other ancillary functions, please record the casting amount instead of the total for the plant and enter $100 \%$ in the last row.

\begin{tabular}{|l|l|l|l|l|l|}
\hline & & & & \multicolumn{2}{|c|}{$\begin{array}{c}\text { Others } \\
\text { (Please Specify) }\end{array}$} \\
\cline { 5 - 6 } & Electricity & $\begin{array}{c}\text { Natural } \\
\text { Gas }\end{array}$ & Propane & & \\
\hline Total Amount & & & & & \\
\hline $\begin{array}{l}\text { Cost of Energy per Physical } \\
\text { Unit, If Applicable }\end{array}$ & & & & & \\
\hline \% Used For Casting & & & & & \\
\hline
\end{tabular}

${ }^{1}$ Casting operations are assumed not to include lighting, air conditioning/heating, heat treat operations, machining operations, painting, plating or other finishing operations. 
7. Please fill in the following table with the types of die casting machines by size and application used in the casting process (one row for each machine).

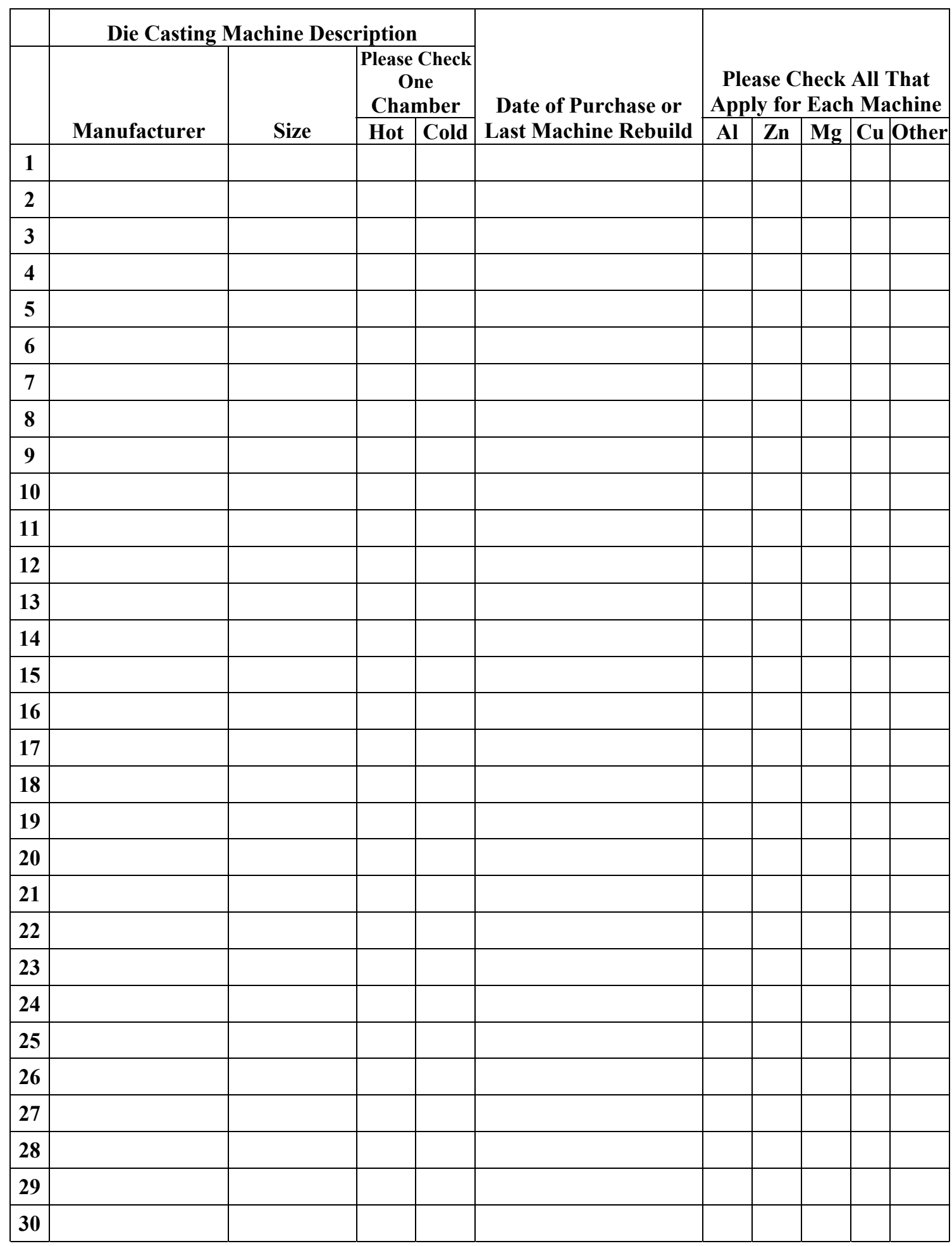


8. Please fill in the following table with the appropriate information on all melt and/or hold furnaces whether or not the furnace is an integral part of a die-casting machine listed previously in question 6 (one row for each furnace).

\begin{tabular}{|c|c|c|c|c|c|c|c|c|c|c|c|c|}
\hline & $\begin{array}{c}\text { Type } \\
\text { For Example, Induction, }\end{array}$ & Pleas & se Chec & k One & & Energy & \begin{tabular}{|l} 
Date of \\
Purchase
\end{tabular} & & ase & $\begin{array}{l}\text { Chec } \\
\text { Ap }\end{array}$ & $\begin{array}{l}\text { k Al } \\
\text { oly }\end{array}$ & II That \\
\hline & $\begin{array}{c}\text { Resistance, } \\
\text { Reverberatory }\end{array}$ & $\begin{array}{l}\text { Melt } \\
\text { Only }\end{array}$ & $\begin{array}{c}\text { Melt \& } \\
\text { Hold }\end{array}$ & $\begin{array}{l}\text { Hold } \\
\text { Only }\end{array}$ & $\begin{array}{l}\text { Furnace } \\
\text { Crucible }\end{array}$ & $\begin{array}{l}\text { Source For } \\
\text { the Furnace }\end{array}$ & \begin{tabular}{|l} 
or Last \\
Rebuild
\end{tabular} & Al & $\mathbf{Z n}$ & Mg & $\mathbf{C u}$ & Other \\
\hline 1 & & & & & & & & & & & & \\
\hline 2 & & & & & & & & & & & & \\
\hline 3 & & & & & & & & & & & & \\
\hline 4 & & & & & & & & & & & & \\
\hline 5 & & & & & & & & & & & & \\
\hline 6 & & & & & & & & & & & & \\
\hline 7 & & & & & & & & & & & & \\
\hline 8 & & & & & & & & & & & & \\
\hline 9 & & & & & & & & & & & & \\
\hline 10 & & & & & & & & & & & & \\
\hline 11 & & & & & & & & & & & & \\
\hline 12 & & & & & & & & & & & & \\
\hline 13 & & & & & & & & & & & & \\
\hline 14 & & & & & & & & & & & & \\
\hline 15 & & & & & & & & & & & & \\
\hline 16 & & & & & & & & & & & & \\
\hline 17 & & & & & & & & & & & & \\
\hline 18 & & & & & & & & & & & & \\
\hline 19 & & & & & & & & & & & & \\
\hline 20 & & & & & & & & & & & & \\
\hline 21 & & & & & & & & & & & & \\
\hline 22 & & & & & & & & & & & & \\
\hline 23 & & & & & & & & & & & & \\
\hline 24 & & & & & & & & & & & & \\
\hline 25 & & & & & & & & & & & & \\
\hline 26 & & & & & & & & & & & & \\
\hline 27 & & & & & & & & & & & & \\
\hline 28 & & & & & & & & & & & & \\
\hline 29 & & & & & & & & & & & & \\
\hline 30 & & & & & & & & & & & & \\
\hline 31 & & & & & & & & & & & & \\
\hline 32 & & & & & & & & & & & & \\
\hline 33 & & & & & & & & & & & & \\
\hline 34 & & & & & & & & & & & & \\
\hline 35 & & & & & & & & & & & & \\
\hline
\end{tabular}




\section{Appendix B}

\section{Energy Flow Chart - Macro View}

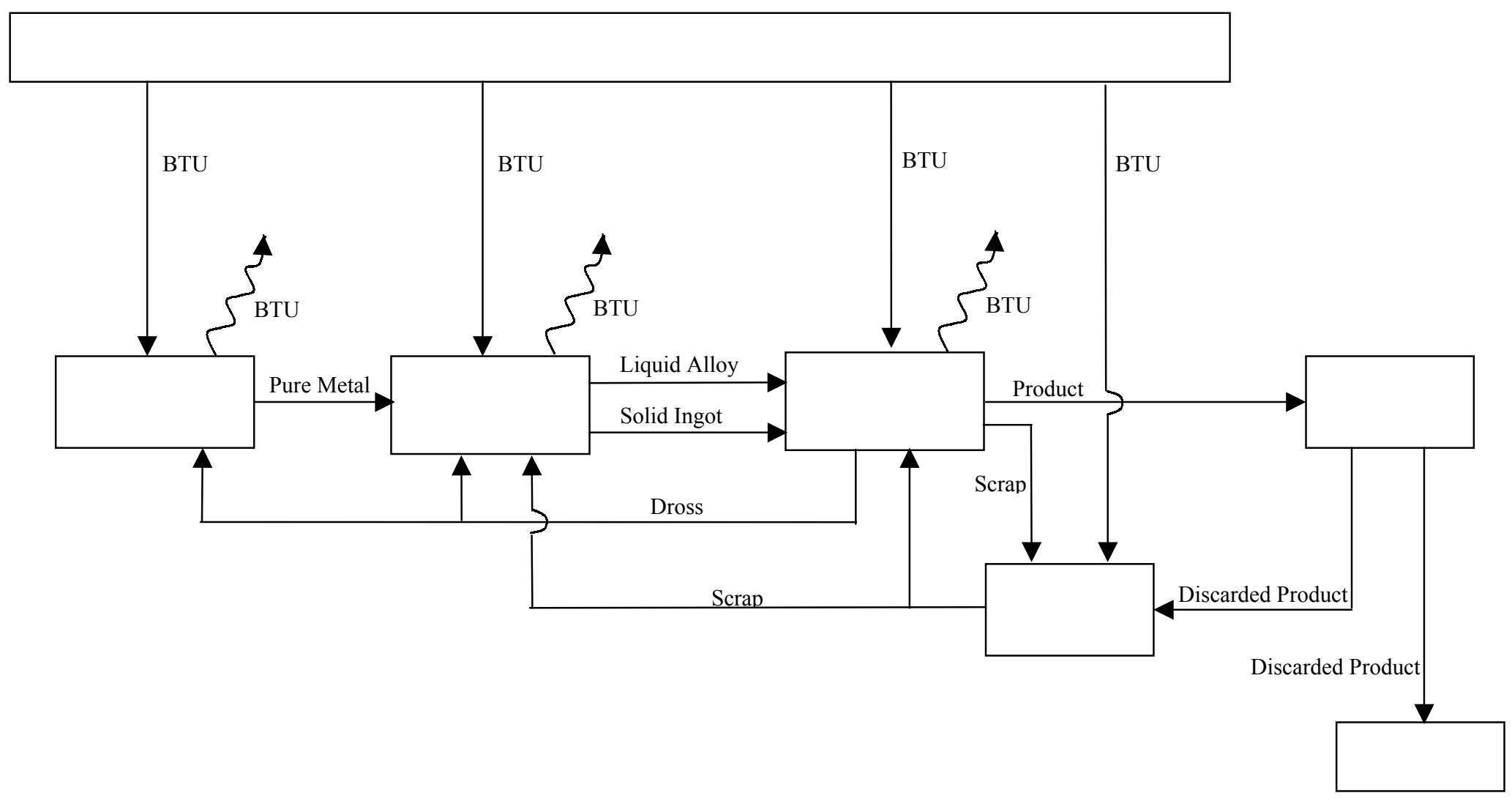

